\title{
Social Science Contributions to Groundwater Governance
}

\author{
Allan Curtis, Michael Mitchell, and Emily Mendham
}

\begin{abstract}
All environments have been modified by human activity and those interactions produce "winners" and "losers". Improvements require changes in human behaviour, especially when these activities deny opportunities for future generations. However, changing human behaviour can be difficult to accomplish. We need to establish better ways to reach and implement sound decisions. For social researchers, a key assumption is that complex and difficult natural resource management (NRM) issues are often best addressed by engaging stakeholders in processes that involve dialogue, learning and action - that is, by engaging and building human and social capital. In this chapter we identify some of the social research principles and practices that will enhance groundwater governance. Social researchers have developed principles and approaches for effective stakeholder engagement, social impact assessment, collaborative approaches for NRM governance and changing the use and management of land and water by rural landholders. We conclude with a discussion of some of the challenges for social scientists contributing to larger integrated programs.
\end{abstract}

\footnotetext{
A. Curtis $(\varangle) \cdot$ E. Mendham

Graham Centre for Agricultural Innovation, Wagga Wagga, NSW, Australia

National Centre for Groundwater Research and Training, Flinders University, South Australia, PO Box 789, Albury, NSW 2640, Australia

e-mail: acurtis@csu.edu.au

M. Mitchell

Landscapes and Policy Hub, National Environmental Research Program, University of Tasmania, PO Box 789, Albury, NSW 2640, Australia
} 


\subsection{Introduction}

Research to improve groundwater management is increasingly recognising the value of drawing on theory and methods from social research. In part, this trend reflects the increasing maturity of those disciplines; and builds on an acceptance that all environments have been modified by human activity and function as co-evolving social-ecological systems (SES), as discussed in Chap. 3. Improvements in environmental condition require changes in human behaviour, especially when these activities deny opportunities for future generations. However, changing human behaviour can be difficult to accomplish. Environmental management is complex because: cause and effect is often uncertain; effective intervention often requires substantial effort over a considerable period of time; it is often difficult to link an intervention with change in resource condition; and in many instances, no single actor is capable of addressing these issues on their own (Curtis and Lefroy 2010). That is, we are often dealing with "wicked problems" (Rittel and Webber 1973). Changing the behaviour of individuals and groups of people is necessary, but not always sufficient. It is also clear that land and water degradation frequently results from deficiencies in governance arrangements (Lockwood et al. 2009). We need to establish better ways to reach and implement sound decisions.

The introductory paragraph above sets out much of the rationale for a chapter that focuses on the social dimensions of groundwater governance. The chapter will provide a review of relevant literature in the social sciences with the aim of identifying the ways those disciplines can contribute to improved ground water governance.

\subsection{Responding to Complexity and Uncertainty}

For social researchers, a key assumption is that "wicked problems" are best addressed by engaging stakeholders in processes that involve dialogue, learning and action - that is, by engaging and building human and social capital. We deliberately distinguish 'engage and build' on the basis that we believe that all people possess inherent abilities and agency (ability to take action to meet their needs). By human capital we mean the skills and abilities of individuals (Castle 2002); and social capital refers to the social relations, networks, trust, norms and institutions (rules) that arise between people when they interact, and which can then lead to further benefits (Sobels et al. 2001). Social researchers typically support more inclusive approaches to Natural Resource Management (NRM) that move beyond government where decisions are largely influenced by markets and bureaucracies to governance where a wider set of actors and arrangements are embraced (Lockwood et al. 2010).

The social research team in Australia's National Centre for Groundwater Research and Training (NCGRT) recently completed a comprehensive review of 
social research focused on groundwater governance. That literature turned out to be a relatively small but expanding body of published work (Mitchell et al. 2011). Almost 300 potentially relevant publications were identified, sorted thematically and assessed for quality in terms of having sound theoretical underpinning and providing credible evidence to support key findings (Mitchell et al. 2012). Some of the ground breaking research identified included Ostrom's publications around the role of social norms in NRM governance that built on her doctoral thesis examining groundwater management in California (Ostrom 1965, 1990). In Australia, the work on justice principles by Syme and colleagues (e.g. Syme et al. 1999) is partly based on research involving reforms in groundwater allocations. This process also enabled the authors to identify some of the key social research principles and practices that will enhance groundwater governance; and identify future social research directions. Those topics are the main foci for this chapter. We will also reflect on our experiences as social researchers contributing to larger integrated research programs which we think are essential if "wicked problems" are to be addressed effectively.

\subsection{Effective Community/Stakeholder Engagement}

For political scientists, civic engagement is a fundamental right and responsibility of citizenship thought to enhance individual's sense of self and well-being. From the 1960s, public engagement became accepted practice with legislation in the USA mandating public involvement in all federal agency decision making (Stankey and Hendee 1975). Public participation was expected to provide an effective means of articulating and incorporating community values in decisions (Creighton 1983), legitimise planning outcomes, reduce conflict, provide feedback on program implementation and outcomes, contribute to community education and improve accountability of government (Daneke 1983; Grima 1983). Of course, the reality and outcomes were often very different. The public often perceived engagement as tokenistic because they thought decisions had already been made; existing inequalities were often entrenched because the privileged with better networks were more likely to be engaged; it was unlikely to be fully representative; those attempting to engage had little idea of how to do that effectively; and the expectation of resolving conflict was unrealistic and ill formed (Kweit and Kweit 1981; Priscoli 1983; Sewell and Phillips 1979; Stankey and Hendee 1975).

Those working in NRM often focus their engagement on local, place-based communities. The local scale can be appropriate for interventions that seek to address local manifestations of environmental problems and to do so by engaging and building human and social capital. However, that focus can also result in the marginalisation of others, including communities of practice, interest and identity (Harrington et al. 2008). There are also questions about the extent the concept of community is used by those with limited understanding or commitment to sound engagement principles and practices. For those operating at larger scales, 
stakeholder engagement might be a more appropriate conceptualisation of the task at hand.

We employ the term "stakeholder" to indicate the range of people who might participate, encompassing those who are influenced by a particular action, organisation or phenomenon, and those who influence that action, organisation or phenomenon (Freeman 1984). In the groundwater context, stakeholders can include scientists, policy makers, farmers, Indigenous people and environmental interests, and there are clear benefits from not excluding key actors (Knüppe and Pahl-Wostl 2011).

There is now abundant advice about how to implement participatory processes (Aslin and Brown 2002). Broad principles for effective stakeholder engagement include: ensure transparency about the purpose of engagement and the level of decision making offered; be inclusive of the range of stakeholders and empower the less advantaged to participate; and develop processes that enable participants to see other perspectives and, therefore, to act "reasonably" rather than "rationally" (Perlgut 1986).

Community self-regulation of groundwater, such as treated in Chap. 9, exemplifies the "citizen control" end of Arnstein's (1969) ladder of citizen participation. However, Arnstein's typology has been criticised for idealising “citizen control", potentially disparaging a wider range of participation approaches that might be appropriate in different contexts (Collins and Ison 2009; Ross et al. 2002). Baldwin (2008), for example, investigated an irrigation community's effort to initiate a system of co-management of groundwater with government through a water planning process in the Lockyer Valley of southern Queensland, Australia. She concluded that groundwater management should draw on values-based rules developed by stakeholders to reflect Ostrom's principles for improving self-governance of common pool resources, but that these should be enforced by government. Taylor et al. (2009) also concluded that government authorities should maintain a role in groundwater management.

In the groundwater literature there are examples where stakeholders have been engaged in planning through participatory modelling (Martínez-Santos et al. 2008), agent-based modelling (Zellner 2008), integrated assessment modelling (Letcher and Jakeman 2003) or cooperative modelling (Tidwell and van den Brink 2008). Henriksen and Barlebo (2008) and more recently Ticehurst et al. (2011) assess the use of Bayesian Networks (BNs) as a tool to enable stakeholder engagement in policy implementation and evaluation. They have also been used as a tool to integrate local ecological knowledge with scientific-based knowledge (Liedloff et al. 2013). BNs are particularly suited to participatory processes because stakeholders are engaged in processes to establish a common language and a shared understanding of causality. In this sense the use of BNs contributes to a process of social learning (Reed et al. 2010; Schusler et al. 2003). The largely hidden and complex nature of groundwater governance provides an ideal context for engagement that embraces social learning. 


\subsection{Social Impact Assessment}

Changes in access to water resources have been a key element of government responses to environmental degradation and water scarcity. In relation to groundwater, these reforms have included reductions in groundwater entitlements and annual allocations, the introduction of trading in groundwater, and changes in rules to allow for the "banking" of surplus water in aquifers for later recovery and use (Contor 2009; Schlager 2006; Thompson et al. 2009). Of course, these changes have the potential to have substantial impacts on stakeholders, including irrigators, industries dependent on irrigation and the nearby towns and cities.

Social impact assessment (SIA) explores how particular events or policies affect people's way of life, their culture and their community (Vanclay and Esteves 2011). SIA may draw on economic assessments, but emphasises the non-monetary effects of an intervention. SIA uses a range of social science disciplines to anticipate the consequences of proposed actions compared to a "no change" scenario. While there are limits to the capacity of the social sciences to predict impacts, plausible scenarios can be constructed, including by drawing on experience with similar interventions in other contexts.

Australian researchers have been at the forefront of developing solid theoretical foundations for SIA (Howitt 1989; Syme and Nancarrow 2006; Syme et al. 1999; Vanclay and Esteves 2011). An important aspect of SIA is the identification of social groups which may be impacted in both negative and positive ways (winners and losers), in particular in relation to individual and community well-being. Amongst other things, SIA examines the unequal distribution of benefits and costs; changes in power structures; implications for family life, health and education; and effects on community cohesion and local organisations. SIA considers impacts on basic human needs (e.g. food, shelter, health, education, work), but extends to consider all of the key aspects of contemporary life in a particular society (e.g. access to banking services; recreation opportunities and infrastructure; quality of information and communication technology; aspirations for the future, including for family succession and education of children).

SIA provides policy makers with a process for identifying and working through issues with stakeholders. A key assumption is that SIA will enable stakeholders (including governments and communities) to identify strategies to mitigate impacts and to monitor impacts over time. Public engagement is a fundamental part of SIA. While there are likely to be benefits from engagement through an SIA in terms of providing a sound information base, clarifying issues, articulating values (i.e. what is important), identifying alternatives and clarifying tradeoffs, and enhancing agency credibility and reducing conflict, these outcomes cannot be assumed. These objectives are reflected in the steps that an SIA typically involves (Vanclay and Esteves 2011).

Public engagement can be costly, requires expertise and, in the case of contentious issues, takes some time (from a few months to years). The scale and duration of the SIA will depend on an initial assessment of the extent of likely impacts 
(e.g. minimal/substantial/transformational), the extent that the intervention will be contentious and the time/resources available.

Despite the potential of SIA, there is always the concern that governments will offer to undertake SIA to placate disgruntled stakeholders and that SIA will occur after a decision has been made. This has largely been the case so far in the past decade with the major water reform process in Australia (Baldwin et al. 2009).

Notwithstanding those remarks, there are international examples where social researchers have been able to make recommendations that have been empowering and proactive (Howitt 1989; Vanclay and Esteves 2011). Of course, social researchers can examine the social impacts of interventions without undertaking a formal SIA. Budds (2009) was able to expose the extent a hydrological assessment undertaken by a contractor for a Chilean government agency enabled wealthier and better educated farmers upstream to secure groundwater allocation rights, including substantial additional amounts of water. Those additional allocations came at the expense of the majority of groundwater users who were peasants located downstream. Apparently, modelling by the contracting agency had failed to consider the widespread illegal use of groundwater, an amount that was estimated to be almost twice that of actual legal extractions. The illegal groundwater use was predominantly by peasant farmers.

Syme et al. (1999) focused on the concepts of fairness and justice as part of their research examining water reform processes, and employed rigorous empirical research to explore these ideas. These authors developed a set of fairness principles and a fairness heuristic that can be used to assess the justice of such decisions. Syme et al. (1999) found that the public considered both distributional and procedural justice when deciding whether water allocation processes were fair. Additionally, they concluded that most of the community assessed fairness as both situational relating to specific water allocation decisions and each community's unique context; and universal - relating to overarching principles, such as a community's rights to have a say in allocation decisions, adherence to principles of procedural justice in the decision-making process, and rights of the environment. These topics have been pursued through subsequent studies by Lukasiewicz et al. (2013).

\subsection{Collaborative Approaches to Groundwater Governance}

Governance involves the interactions between social structures, processes and traditions that determine how power in society influences how decisions are made, how responsibilities are exercised and who has a say in all of this (Lockwood et al. 2010). The shift to governance reflects an approach to decision making that moves beyond markets and bureaucracies to be inclusive of a wider set of actors and arrangements (Lockwood et al. 2010). For Mukherji and Shah (2005) "groundwater governance" implied a shift from expert-driven processes derived from the 
"mathematical model-building exercises" of hydrologists and "the formulation and implementation of groundwater laws" by water managers. In part, the move towards governance reflects the need to establish better ways to reach and implement sound decisions. But groundwater governance has its own challenges, including those related to incomplete property rights, compliance with rules when the resource is largely invisible, lack of knowledge about the interconnections with surface and groundwater, the impact of groundwater use at considerable distance from where extraction occurs (Bolin et al. 2008), and conflicting interpretations over sustainable use of groundwater (Shriver and Peaden 2009; Weber et al. 2011) derived in part from the problematic construct of sustainable yield (Richardson et al. 2011; Seward et al. 2006).

There is increased interest in exploring the potential for community selfregulation of groundwater given the trend to devolve responsibilities away from centralised authorities (Chap. 9; Wilder and Lankao 2006), problems associated with privatisation (Bluemling et al. 2010), and the difficulties government agencies face in regulating groundwater use and preventing over extraction (van Steenbergen 2006). Defined as the "collective management of groundwater by water users" (López-Gunn 2003; Wester et al. 2011), the concept is also referred to as local, community-based and/or participatory management (Sandoval 2004; van Steenbergen 2006; Yamamoto 2008). In Gujarat, India, for example, government agencies in partnership with local non-governmental organisations have nurtured the development of farmer cooperatives and other credible local organisations (Tewari and Khanna 2005). Drawing on examples from developing economies, van Steenbergen (2006) concluded that informal norms based on moral imperatives (or "injunctive" social norms) have been the most effective means to limit the negative consequences of excessive private development of groundwater resources. Others have examined the difficulties that can be faced when authorities attempt to promote self-regulation of groundwater (López-Gunn and Cortina 2006; Mustafa and Qazi 2007; Wester et al. 2011).

Our review of the literature suggests that self-regulation is most effective when it evolves through collective action, building on the strength of existing social capital. Ross and Martinez-Santos (2010) confirmed Ostrom's (1990) conclusion that selfregulation is more likely to work for smaller scale groundwater systems than larger ones. Existing literature has little to say about how to build and engage community capacity for self-organisation. Yet there is a body of research exploring attributes of social capital that could provide researchers examining groundwater management with a rich pool of theory and research tools to draw upon. For example, de Vos and van Tatenhove (2011) described the evolution of trust relationships between fishers and government through the development of co-management arrangements in the Netherlands. In their evaluation of regional NRM governance in Australia, Lockwood et al. (2010) identified seven governance principles and provided a set of examples of how the elements of each principle could be evaluated. 


\subsection{Influencing the Use and Management of Land and Water by Rural Landholders}

In developed and developing economies rural landholders are key stakeholders in groundwater governance. Groundwater access and the quality of that water are often critical factors influencing human wellbeing (e.g. food security, incomes, employment and health). The land use and management actions of rural landholders also influence the integrity of aquifers and in turn, the condition of key environmental assets. However, groundwater research has focused mostly on the resource, rather than the actors who use and manage the resource (Hammani et al. 2009). Bekkar et al. (2009), Kuehne et al. (2008) and Albrecht (1990, 1995) are some of the small set of researchers who have explored the links between landholder behaviour and influences on landholder adoption in the groundwater context.

Engaging rural landholders in practice change is complex and difficult, not least because there is a potentially large set of factors (personal, societal) influencing their decisions (Mazur et al. 2013; Pannell et al. 2006); and these vary according to each technology, each landholder, each farming context and over time (Curtis and Mendham 2011). Figure 19.1 provides a useful framework for those attempting to identify the most relevant factors in any context. Even the concept of adoption is problematic. For example, when does a trial of a new practice become a change that represents adoption/implementation?

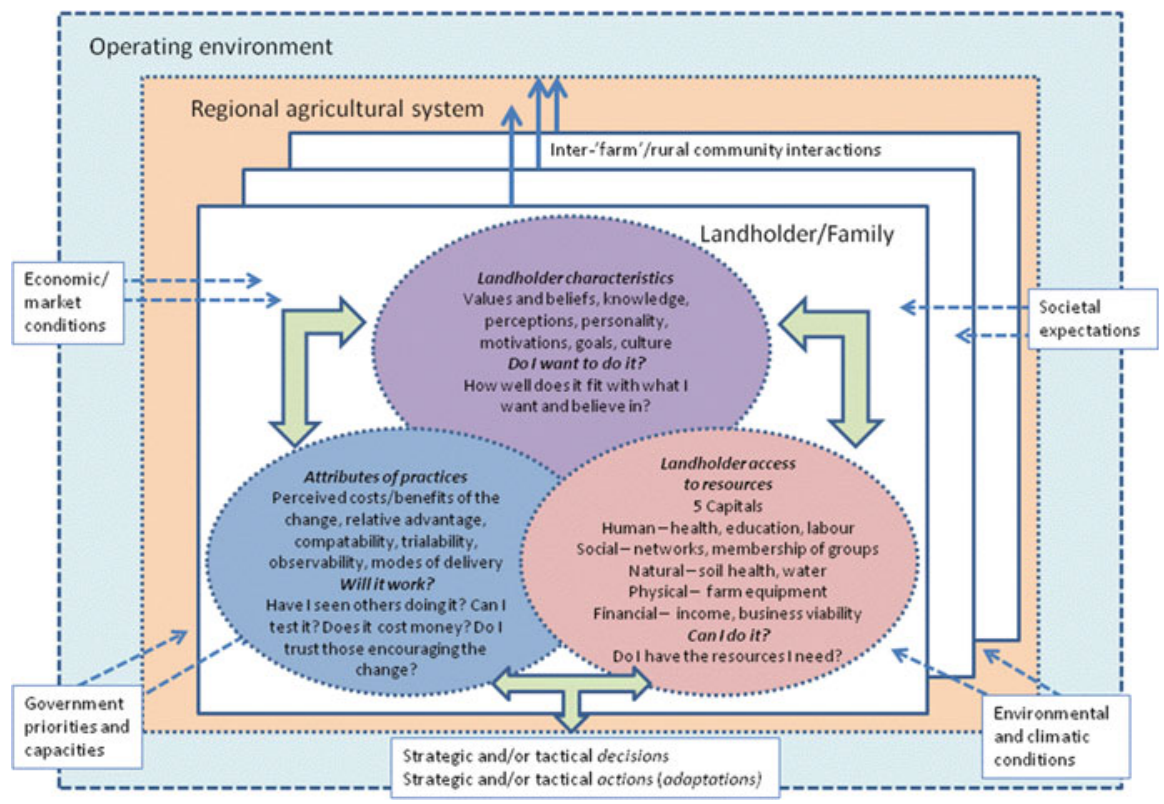

Fig. 19.1 Understanding landholder decision making (Adapted from Mazur et al. 2008) 
Personal engagement with individual landholders can be very effective. However, personal engagement is not always possible or necessary and it may be sufficient to develop a suite of policy instruments from across the "five P's: prescription, penalty, persuasion, property rights (and markets) and payment that meet the diverse needs of landholders (Salzman 2005).

The selection of policy instruments should be based on an assessment of the extent we are confident in the science underpinning decisions about "where we are headed and how to get there" (Curtis and Lefroy 2010); the adoptability of the technology (landuse or management practice); and the relative costs of different approaches, including transaction costs (Pannell 2011).

Where we are reasonably confident about the appropriateness of the outcomes we are seeking and the science that links the proposed intervention and desired outcomes, we can apply best-practice recommendations. If that is the case, we then need to make an assessment of the adoptability of those practices by rural landholders. For example, if awareness, knowledge or management skills are the issue, then activities that address those issues are appropriate. If the issue is lack of confidence in a recommended practice, perhaps because elements of the technology might be unproven or complex, then activities to trial those practices in the local area might be appropriate. If the issue is that the change involves considerable expense and appears to offer limited financial returns to landholders, then some form of cost-sharing between government and private landholders might be appropriate. Of course, even the implementation of best practices should be undertaken within an adaptive management framework.

We live in an increasingly modified environment. Having accepted that reality, it makes little sense to base NRM around the objective of restoring the environment to "pristine" condition. We must also recognise that concepts such as "pristine," "safe" or "sustainable yield" are human constructs that are changing over time (Alley and Leake 2004; Pierce et al. 2013).

A way forward is to bring stakeholders together to negotiate desired condition outcomes for specific environmental assets or systems (e.g. a water catchment) and for these condition targets to be the basis for developing and adapting strategies to move towards more desirable futures (Curtis and Lefroy 2010).

Rural landholders would be a key stakeholder in these processes and would be actively engaged in the dialogue, learning and action (not just on their property) that would occur in such an iterative process. The literature around resilience thinking and social learning provides important theoretical foundations and much practical guidance for those contemplating this type of engagement with rural landholders.

While improved environmental condition or health is the desired outcome of NRM interventions, considerable focus will be on engaging and building human and social capital that underpin much of the capacity of any community to respond to the challenges of sustainability. These concepts were introduced earlier and we expand those explanations here. Human capital embraces the attributes of a population, its training and skills, health and cultural diversity. Social capital refers to the attributes of relationships established in a community that enables participants to act together more effectively. These attributes include the structural social capital 
of networks and partnerships; and the cognitive social capital of trust, norms, institutional arrangements and reciprocal relationships that predispose people to cooperative behaviour and reduce transaction costs (Sobels et al. 2001). A focus on developing positive social norms is one strategy that can be used to influence adoption of new practices (Minato et al. 2010). Of course, if changes in human and social capital are part of our intermediate objectives as we strive to achieve our environmental condition targets, we must develop measures to evaluate those outcomes.

There is a trend in social research focused on environmental behaviour to draw on Values-Beliefs-Norms (personal) (VBN) theory (Stern et al. 1999). Our view is that this and related theories arising from the Theory of Planned Behaviour (Ajzen 1991) are adequate for explaining the conservation behaviours of the general public, but do not adequately account for the larger set of factors influencing decisions by rural landholders (Pannell et al. 2006). These additional factors include attributes of specific practices; government interventions to influence landholder decisions; global commodity prices; and the existence/development of social norms through local organizations [refer to Fig. 19.1]. It is also important to note that while values, beliefs and personal norms (VBN) may mediate or moderate some of these other factors, it is difficult to change these attributes in the short or medium term. At the same time, we know from research that interventions that focus on engaging and building human and social capital, including through one-toone extension, involvement in short courses and participation in field days have positive effects on adoption (Curtis and Mendham 2011). An additional layer of complexity is emerging as a result of the trend to non-farmer (by occupation) rural landholders, and a substantial cohort of absentee owners (Mendham and Curtis 2010).

\subsection{Conclusions}

\subsubsection{Future Research}

Drawing on our review, our knowledge of the more expansive social research contributions to NRM, and our understanding of the groundwater context, we have identified a number of research topics that could be pursued by social researchers in order to achieve more integrated groundwater management. Sustainable yield remains a problematic concept for groundwater managers and scientists. Social researchers could make an important contribution here by describing, explaining, and perhaps assisting in reconciling the different ways stakeholders define or interpret "sustainable yield" and how those different interpretations affect their attitudes and behaviours, and in turn, policy and management.

The contemporary proliferation of coal seam gas (CSG) developments in Australia, Canada, the United States and elsewhere, which has the potential to impact negatively on aquifer integrity and water quality, also provides a context to 
examine stakeholder perceptions of risk and trust. A key issue and one of considerable theoretical interest would be the nature of any relationships between risk interpretation and trust and their influence on the social acceptability of CSG by different stakeholders. While there is an established body of research into the social acceptability of carbon capture and storage (e.g. van Alphen et al. 2007) and risk perceptions associated with groundwater contamination (e.g. Vandermoere and Vanderstraeten 2014), research into stakeholder perceptions of risks associated with CSG is in its infancy (Jacquet 2009; Shackley et al. 2006). Given the scale of public controversy over CSG mining, we believe there is considerable scope to inform those policy debates by investigating how CSG risks are interpreted and communicated.

Theoretical constructs and frameworks associated with justice, collective action, trust and social norms can be explored further as researchers contribute to efforts to undertake social impact assessment processes, develop improved collaborative management and community self-regulation, and identify interventions designed to influence landholder behaviour. In this way, developments in theory will be underpinned by practice.

\subsubsection{Social Scientists Contributing to Integrated Research}

Working as social researchers contributing to multi-disciplinary and interdisciplinary research programs has had many benefits. Regular and structured interactions with scientists have increased our understanding of ecology and hydrogeology and the assumed links between property management and environmental condition outcomes. As part of research teams we have found it easier to access informants and data layers held by spatial scientists. There have also been benefits in terms of being exposed to different perspectives and approaches that have led to improved problem definition and the interpretation of results. These interactions improved the efficiency of the research process, the quality of research outcomes and the extent research has influenced policy and management.

At the same time, our experience has been mixed in that offers to engage with other disciplines have often been ignored. That has typically occurred at the start when research priorities are being developed and resources allocated. Our experience has been that over time, most researchers develop an appreciation of the relevance of social research and the capacity of the social sciences to contribute to integrated approaches. So, it is critical for social researchers to be engaged from the outset in problem definition and setting research priorities. It is also important for social researchers to articulate what they see as the cutting-edge social research rather than being considered as service providers who can support the tasks of stakeholder engagement or social impact assessment. Of course, social researchers must be open to offers to contribute to these research teams and to explain and justify their research approaches. 


\subsection{Summarised Points}

1. Difficult or 'wicked' natural resource management (NRM) issues are often best addressed by engaging stakeholders in processes that involve dialogue, learning and action to build and engage social and human capital.

2. Human and social capital underpins much of the capacity of any community to respond to the challenges of sustainability.

3. Principles and practices developed by social researchers that will enhance groundwater governance include: approaches for effective stakeholder engagement, social impact assessment, collaborative approaches for NRM governance and changing the use and management of land and water by rural landholders.

4. When conducting integrated research, it is critical for social researchers to be engaged from the outset in problem definition and setting research priorities.

Open Access This chapter is distributed under the terms of the Creative Commons AttributionNoncommercial 2.5 License (http://creativecommons.org/licenses/by-nc/2.5/) which permits any noncommercial use, distribution, and reproduction in any medium, provided the original author(s) and source are credited.

The images or other third party material in this chapter are included in the work's Creative Commons license, unless indicated otherwise in the credit line; if such material is not included in the work's Creative Commons license and the respective action is not permitted by statutory regulation, users will need to obtain permission from the license holder to duplicate, adapt or reproduce the material.

\section{References}

Ajzen I (1991) The theory of planned behavior. Organ Behav Hum Decis Process 50(2):179-211. doi:10.1016/0749-5978(91)90020-T

Albrecht DE (1990) The adaptations of farmers in an era of declining groundwater supplies. South Rural Sociol 7:46-62

Albrecht DE (1995) A comparison of the views of farmers and the nonfarm public regarding resource use the case of Texas groundwater. South J Rural Sociol 11(1):1-15

Alley WM, Leake SA (2004) The journey from safe yield to sustainability. Ground Water 42 (1):12-16. doi:10.1111/j.1745-6584.2004.tb02446.x

Arnstein S (1969) A ladder of citizen participation. J Am Inst Plann 35(4):216-224. doi:10.1080/ 01944366908977225

Aslin H, Brown V (2002) Terms of engagement: a toolkit for community engagement for the Murray-Darling Basin. Bureau of Rural Sciences, Canberra. http://adl.brs.gov.au/brsShop/ html/brs_prod_90000002788.html. Accessed 30 July 2011

Baldwin C (2008) Rules for the magic pudding: managing Lockyer groundwater. Soc Altern 27 (3):26-31

Baldwin C, O'Keefe VO, Hamstead M (2009) Reclaiming the balance: social and economic assessment - lessons learned after ten years of water reforms in Australia. Australas J Environ Manag 16(2):70-83

Bekkar Y, Kuper M, Errahj M et al (2009) On the difficulty of managing an invisible resource: farmers' strategies and perceptions of groundwater use, field evidence from Morocco. Irrig Drain 58(S3):S252-S263. doi:10.1002/ird.527 
Bluemling B, Pahl-Wostl C, Yang H et al (2010) Implications of stakeholder constellations for the implementation of irrigation rules at jointly used wells: cases from the North China Plain, China. Soc Nat Resour 23(6):557-572. doi:10.1080/08941920903376998

Bolin B, Collins T, Darby K (2008) Fate of the Verde: water, environmental conflict, and the politics of scale in Arizona's central highlands. Geoforum 39(3):1494-1511. doi:10.1016/j. geoforum.2008.02.003

Budds J (2009) Contested $\mathrm{H}_{2} \mathrm{O}$ : science, policy and politics in water resources management in Chile. Geoforum 40(3):418-430. doi:10.1016/j.geoforum.2008.12.008

Castle EN (2002) Social capital: an interdisciplinary concept. Rural Sociol 67(3):331-349

Collins K, Ison R (2009) Jumping off Arnstein's ladder: social learning as a new policy paradigm for climate change adaptation. Environ Policy Gov 19(6):358-373. doi:10.1002/eet.523

Contor BA (2009) Groundwater banking in aquifers that interact with surface water: aquifer response functions and double-entry accounting. J Am Water Resour Assoc 45 (6):1465-1474. doi:10.1111/j.1752-1688.2009.00378.x

Creighton JL (1983) The use of values: public participation in the planning process. In: Daneke GA, Garcia MW, Priscoli JD (eds) Public involvement and social impact assessment. Westview Press, Boulder, pp 143-160

Curtis A, Lefroy EC (2010) Beyond threat- and asset-based approaches to natural resource management in Australia. Aust J Environ Manag 17(3):6-13

Curtis AL, Mendham E (2011) Bridging the gap between policy and management of natural resources. In: Vanclay F, Pannell DJ (eds) Changing land management: adoption of new practices by rural landholders. CSIRO Publishing, Collingwood, pp 153-176

Daneke A (1983) Public involvement: what, why, and how. In: Daneke GA, Garcia MW, Priscoli JD (eds) Public involvement and social impact assessment. Westview Press, Boulder, pp 11-34

de Vos BI, van Tatenhove JPM (2011) Trust relationships between fishers and government: new challenges for the co-management arrangements in the Dutch flatfish industry. Mar Policy 35 (2):218-225. doi:10.1016/j.marpol.2010.10.002

Freeman RE (1984) Strategic management: a stakeholder approach. Pitman, Boston

Grima AP (1983) Analyzing public inputs to environmental planning: a summary and discussion of public involvement in Great Lakes management. In: Daneke GA, Garcia MW, Priscoli JD (eds) Public involvement and social impact assessment. Westview Press, Boulder, pp 111-119

Hammani A, Hartani T, Kuper M et al (2009) Paving the way for groundwater management: transforming information for crafting management rules. Irrig Drain 58(S3):S240-S251. doi:10.1002/ird.521

Harrington C, Curtis A, Black R (2008) Locating communities in natural resource management. J Environ Policy Plan 10(2):199-215

Henriksen HJ, Barlebo HC (2008) Reflections on the use of Bayesian belief networks for adaptive management. J Environ Manage 88(4):1025-1036. doi:10.1016/j.jenvman.2007.05.009

Howitt R (1989) Social impact assessment and resource development: issues from the Australian experience. Aust Geogr 20(2):153-166. doi:10.1080/00049188908702987

Jacquet J (2009) Energy boomtowns and natural gas: implications for Marcellus Shale local governments and rural communities. NERCRD Rural Development paper no. 43, Northeast Regional Center for Rural Development, Pennsylvania State University, University Park

Knüppe K, Pahl-Wostl C (2011) A framework for the analysis of governance structures applying to groundwater resources and the requirements for the sustainable management of associated ecosystem services. Water Resour Manag 25(13):3387-3411. doi:10.1007/s11269-011-9861-7

Kuehne G, Bjornlund H, Cheers B (2008) Identifying common traits among Australian irrigators using cluster analysis. Water Sci Technol 58(3):587-595. doi:10.2166/wst.2008.681

Kweit MG, Kweit RW (1981) Implementing citizen participation in a bureaucratic society. Praeger, New York

Letcher R, Jakeman A (2003) Application of an adaptive method for integrated assessment of water allocation issues in the Namoi River catchment. Australia. Integr Assess 4(2):73-89 
Liedloff AC, Woodward EL, Harrington GA et al (2013) Integrating indigenous ecological and scientific hydro-geological knowledge using a Bayesian Network in the context of water resource development. J Hydrol 499:177-187. doi:10.1016/j.jhydrol.2013.06.051

Lockwood M, Davidson J, Stratford E et al (2009) Multi-level environmental governance: lessons from Australia for natural resource management. Aust Geogr 40(2):169-186

Lockwood M, Davidson J, Curtis A et al (2010) Governance principles for natural resource management. Soc Nat Resour 23(10):986-1001. doi:10.1080/08941920802178214

López-Gunn E (2003) The role of collective action in water governance: a comparative study of groundwater user associations in La Mancha aquifers (Spain). Water Int 28(3):367-378. doi:10.1080/02508060308691711

López-Gunn E, Cortina L (2006) Is self-regulation a myth? Case study on Spanish groundwater user associations and the role of higher-level authorities. Hydrogeol J 14(3):361-379. doi:10. 1007/s10040-005-0014-z

Lukasiewicz A, Syme GJ, Bowmer KH et al (2013) Is the environment getting its fair share? An analysis of the Australian water reform process using a social justice framework. Soc Justice Res 26:231-252

Martínez-Santos P, Llamas MR, Martínez-Alfaro PE (2008) Vulnerability assessment of groundwater resources: a modelling-based approach to the Mancha Occidental aquifer, Spain. Environ Model Software 23(9):1145-1162. doi:10.1016/j.envsoft.2007.12.003

Mazur N, Curtis A, Thwaites R et al (2008) Rural landholder adaptation to climate change: social research perspectives. Landscape Logic Research report no. 5, University of Tasmania, Hobart. http://athene.riv.csu.edu.au/ acurtis/reports/No\%205_P2_Mazur_climate\%20change.pdf

Mazur N, Curtis A, Rogers M (2013) Do you see what I see? Rural landholders' belief in climate change. Soc Nat Resour 26(1):75-85. doi:10.1080/08941920.2012.686650

Mendham E, Curtis A (2010) Taking over the reins: trends and impacts of changes in rural property ownership. Soc Nat Resour 23(7):653-668. doi:10.1080/08941920801998893

Minato W, Curtis A, Allan C (2010) Social norms and natural resource management in a changing rural community. J Environ Policy Plan 12(4):381-403. doi:10.1080/1523908X.2010.531084

Mitchell M, Curtis A, Sharp E et al (2011) Social research to improve groundwater governance: Literature review. ILWS report no. 66, Institute for Land, Water and Society, Charles Sturt University, Albury. http://www.csu.edu.au/research/ilws/research/reports2011.htm

Mitchell M, Curtis A, Sharp E et al (2012) Directions for social research to underpin improved groundwater management. J Hydrol 448-449:223-231. doi:10.1016/j.jhydrol.2012.04.056

Mukherji A, Shah T (2005) Groundwater socio-ecology and governance: a review of institutions and policies in selected countries. Hydrogeol J 13(1):328-345. doi:10.1007/s 10040-005-0434-9

Mustafa D, Qazi MU (2007) Transition from karez to tubewell irrigation: development, modernization, and social capital in Balochistan, Pakistan. World Dev 35(10):1796-1813. doi:10.1016/ j.worlddev.2007.06.002

Ostrom E (1965) Public entrepreneurship: a case study in ground water basin management. Dissertation, University of California, Los Angeles

Ostrom E (1990) Governing the commons: the evolution of institutions for collective action. Cambridge University Press, Cambridge

Pannell D (2011) Policy perspectives on changing land management. In: Pannell D, Vanclay F (eds) Changing land management: adoption of new practices by rural landholders. CSIRO Publishing, Melbourne, pp 177-187

Pannell DJ, Marshall GR, Barr N et al (2006) Understanding and promoting adoption of conservation technologies by rural landholders. Aust J Exp Agric 46(11):1407-1424

Perlgut D (1986) Introduction. In: Sarkissian W, Perlgut D, Ballard E (eds) The community participation handbook: resources for public involvement in the planning process. Impact Press, Roseville, pp 1-6

Pierce SA, Sharp JM, Guillaume JA et al (2013) Aquifer-yield continuum as a guide and typology for science-based groundwater management. Hydrogeol J 21(2):331-340. doi:10.1007/ s10040-012-0910-y 
Priscoli JD (1983) The citizen advisory group as an integrative tool in regional water resources planning. In: Daneke GA, Garcia MW, Priscoli JD (eds) Public involvement and social impact assessment. Westview Press, Boulder, pp 79-87

Reed MS, Evely AC, Cundill G et al (2010) What is social learning? Ecol Soc 5(4):r1. [online] URL: http://www.ecologyandsociety.org/vol15/iss4/resp1/

Richardson S, Evans R, Harrington G (2011) Connecting science and engagement: setting groundwater extraction limits using a stakeholder-led decision-making process. In: Connell D, Grafton RQ (eds) Basin futures: water reform in the Murray-Darling Basin. ANU e-press, Canberra, pp 351-366

Rittel HWJ, Webber MM (1973) Dilemmas in a general theory of planning. Policy Sci 4 (2):155-169. doi:10.1007/BF01405730

Ross A, Martinez-Santos P (2010) The challenge of groundwater governance: case studies from Spain and Australia. Reg Environ Chang 10(4):293-310. doi:10.1007/s10113-009-0086-8

Ross H, Buchy M, Proctor W (2002) Laying down the ladder: a typology of public participation in Australian natural resource management. Aust J Environ Manag 9(4):205-217

Salzman J (2005) Creating markets for ecosystem services: notes from the field. N Y Univ Law Rev 80:870-961

Sandoval R (2004) A participatory approach to integrated aquifer management: the case of Guanajuato State, Mexico. Hydrogeol J 12(1):6-13. doi:10.1007/s10040-003-0311-3

Schlager E (2006) Challenges of governing groundwater in U.S. western states. Hydrogeol J 14 (3):350-360. doi:10.1007/s10040-005-0012-1

Schusler TM, Decker DJ, Pfeffer MJ (2003) Social learning for collaborative natural resource management. Soc Nat Resour 16(4):309-326. doi:10.1080/08941920390178874

Seward P, Xu Y, Brendonck L (2006) Sustainable groundwater use, the capture principle, and adaptive management. Water SA 32(4):473-482

Sewell WRD, Phillips SD (1979) Models for the evaluation of public participation programs. Nat Resour J 19:337-358

Shackley S, Mander S, Reiche A (2006) Public perceptions of underground coal gasification in the United Kingdom. Energ Policy 34(18):3423-3433. doi:10.1016/j.enpol.2005.07.010

Shriver TE, Peaden C (2009) Frame disputes in a natural resource controversy: the case of the Arbuckle Simpson Aquifer in south-central Oklahoma. Soc Nat Resour 22(2):143-157. doi:10. 1080/08941920801973789

Sobels J, Curtis A, Lockie S (2001) The role of Landcare group networks in rural Australia: exploring the contribution of social capital. J Rural Stud 17(3):265-276. doi:10.1016/S07430167(01)00003-1

Stankey GH, Hendee JC (1975) Applied social research can improve public participation in resource decision making. Rural Sociol 40(1):67-74

Stern PC, Dietz T, Abel T et al (1999) A value-belief-norm theory of support for social movements: the case of environmentalism. Hum Ecol Rev 6(2):81-97

Syme GJ, Nancarrow BE (2006) Achieving sustainability and fairness in water reform: a Western Australian case study. Water Int 31(1):23-30. doi:10.1080/02508060608691911

Syme GJ, Nancarrow BE, McCreddin JA (1999) Defining the components of fairness in the allocation of water to environmental and human uses. J Environ Manage 57(1):51-70. doi:10.1006/jema.1999.0282

Taylor B, de Loe R, Kreutzwiser R et al (2009) Local groundwater management studies in Ontario, Canada: a case for retaining a role for the state in community-based water research. Aust $\mathrm{J}$ Water Resour 13(1):69-80

Tewari DD, Khanna S (2005) Building and energizing water institutions: a case study of irrigation management transfer in Gujarat. J Environ Syst 31(3):201-221. doi:10.2190/ES.31.3.a

Thompson CL, Supalla RJ, Martin DL et al (2009) Evidence supporting cap and trade as a groundwater policy option for reducing irrigation consumptive use. J Am Water Resour Assoc 45(6):1508-1518. doi:10.1111/j.1752-1688.2009.00384.x 
Ticehurst JL, Curtis A, Merritt WS (2011) Using Bayesian Networks to complement conventional analyses to explore landholder management of native vegetation. Environ Model Software 26:52-65

Tidwell VC, van den Brink C (2008) Cooperative modeling: linking science, communication, and ground water planning. Ground Water 46(2):174-182. doi:10.1111/j.1745-6584.2007.00394.x

van Alphen K, van Voorst tot Voorst Q, Hekkert MP et al (2007) Societal acceptance of carbon capture and storage technologies. Energ Policy 35(8):4368-4380. doi:10.1016/j.enpol.2007. 03.006

van Steenbergen F (2006) Promoting local management in groundwater. Hydrogeol J 14 (3):380-391. doi:10.1007/s10040-005-0015-y

Vanclay F, Esteves AM (eds) (2011) New directions in social impact assessment. Edward Elgar, Cheltenham

Vandermoere F, Vanderstraeten R (2014) Back and forward to the future: an explorative study of public responses to urban groundwater contamination. J Environ Plan Manag 57(5):720-732. doi:10.1080/09640568.2013.763773

Weber EP, Memon A, Painter B (2011) Science, society, and water resources in New Zealand: recognizing and overcoming a societal impasse. J Environ Policy Plan 13(1):49-69. doi:10. 1080/1523908x.2011.564414

Wester P, Sandoval R, Hoogesteger J (2011) Assessment of the development of aquifer management councils (COTAS) for sustainable groundwater management in Guanajuato, Mexico. Hydrogeol J 19(4):889-899. doi:10.1007/s10040-011-0733-2

Wilder M, Lankao PR (2006) Paradoxes of decentralization: water reform and social implications in Mexico. World Dev 34(11):1977-1995. doi:10.1016/j.worlddev.2005.11.026

Yamamoto S (2008) Groundwater management in rice terraces: a case study of a lakeside community in Shiga Prefecture, Japan. Local Environ 13(5):449-460. doi:10.1080/ 13549830701809775

Zellner ML (2008) Embracing complexity and uncertainty: the potential of agent-based modeling for environmental planning and policy. Plan Theory Pract 9(4):437-457. doi:10.1080/ 14649350802481470 